\title{
The Old Public Policy of Regional Development: The Case of Fiscal Incentives in Maranhão
}

\author{
Fernando Silva Lima ${ }^{1}$, Juliana Santos Viana ${ }^{1} \&$ Dauana de Sousa Silva ${ }^{1}$ \\ ${ }^{1}$ Federal Institute of Education, Science and Technology of Maranhão, Bacabal Campus, Avenida Governador João \\ Alberto, Areal Neighborhood, Bacabal, Brazil \\ Correspondence: Fernando Silva Lima, Federal Institute of Education, Science and Technology of Maranhão, \\ Bacabal Campus, Avenida Governador João Alberto, CEP: 65.700-000, Areal Neighborhood, Bacabal, Brazil.
}

Received: April 26, 2018

Accepted: April 25, 2018

Online Published: June 22, 2018

doi:10.5430/ijba.v9n4p25

URL: https://doi.org/10.5430/ijba.v9n4p25

\begin{abstract}
This article tried to answer the following question: did the fiscal incentives in Maranhão manage to maintain the increase in the number of jobs and stimulate regional development? Therefore, it is justified that the study of fiscal incentives is essential to know if this policy was efficient and effective in the development of the regions of the state. The general objective is to analyze the impact of fiscal incentives in Maranhão on the generation of employment and income between 2008 and 2017. The methodology of this study is bibliographical and field. This study concludes that tax incentives have not been able to maintain the growth of the balance of jobs in the last 4 years analyzed.
\end{abstract}

Keywords: incentive, public policy, regional development

\section{Introduction}

The need for the collection of taxes is noticeable, since the public sector basically needs maintenance in several areas such as health, education and public safety, so it is possible to highlight the restricted use of tax incentives, thus seeking to reduce taxes in the circulation of products sold and strengthen both the regional and national economies. (LIMA, 2015, p.27)

It is understood that tax incentives are small stewardships given to companies in order to reduce the tax burden for a given time. However, Lima (2015, p 28) believes that these incentives are born from a model that was implanted by other public managers whose results were positive.

Thus, it has as a research problem, the lack of efficiency in the planning of the management of the public policies of fiscal incentives to promote a regional development aimed at the generation of employment and income in the state governments of Brazil.

In this context, the granting of tax incentives for this purpose is not a fiscal policy, but a local and regional development policy combined with an industrial policy, which uses a fiscal instrument to stimulate the economic sectors, but depending on the form and intensity, these incentives may or may not be harmful in all localities or states, so that a possible loss of taxes should be offset by the benefits generated by industrial densification and the increase in the supply of jobs in the backward regions (AMARAL FILHO, 2003).

But it is perceived that they sometimes grant incentives without giving importance to local productive arrangements and the demands of the regions in terms of infrastructure and labor that enable local and regional economic strengthening.

For Bercovici (2003, p. 58) development is a necessary condition for social welfare, and the state is its main driver through planning, which involves the expansion of individual and collective opportunities generated by economic growth.

Therefore, the way to create tax incentives should be analyzed because it can avoid a huge bottleneck between companies and the government itself because, in some cases, tax incentives can not trigger the expected economic growth and this can lead the government to tax so that the same, do not have losses in the collection of taxes in the public coffers. 
Therefore, the research problem resumes the questioning: did the fiscal incentives in Maranhão manage to maintain the increase in the number of jobs and stimulate regional development?

The following situation is hypothesized: the concession of fiscal incentives in the state of Maranhão stimulates companies to generate jobs in the region, but they can not maintain the same growth because in relation to GDP, the same depends on the production and consumption of products.

This study is justified by understanding that fiscal incentives are an old practice of governments that focus on stimulating the local and regional economy, and it is fundamental to study whether this policy has been efficient and effective in the development of the poorest regions in the Maranhão.

The reason for this study is to contribute to the fiscal balance in the particular state, with the most deprived regions of infrastructure, according to Imesc (2016, p.9), "the impacts of the recession and the fiscal crisis have accumulated fall of R \$ 425 million in the period January-August 2016 (-7.5\%), adding up to the R \$ 452.2 Million decrease over the course of 2015, "and this may damage the state when investing in the areas such as health, education and basic sanitation, since financial resources from tax collection may be lacking.

It is worth mentioning that this study intends to collaborate with the state of Maranhão, showing the economic scenario regarding employability in the region after the concession of fiscal incentives, since, thus, the government can analyze how to stimulate and warm the local economy without " fiscal incentive gap with the sectors not benefited "(LIMA, 2015, p.56).

Therefore, this study is relevant both for the academic environment and for society, since it can contribute to the regional development of Maranhão in relation to tax management, having as object of study the economic activities encouraged in the state of Maranhão.

Therefore, the general objective of this study is to analyze the impact of fiscal incentives in Maranhão on the generation of employment and income between 2008 and 2017. Specific objectives are: to identify the amount of active tax incentives; to verify the correlation of the absolute variation of jobs by the economic activities stimulated with the amount of the absolute variation of jobs in Maranhão; to analyze the correlation of the jobs generated by the activities stimulated in Maranhão and with the jobs generated by the same economic activity in the Northeast of Brazil and to analyze the relation of the balance of jobs in the activities stimulated with the performance of the state GDP in Maranhão.

\section{The Maranhão and Its Economic Challenges}

It is understood that Maranhão developed economically without depending on the fiscal incentive policy because, when Brazil was a colony of Portugal and the state was a province, the plantation of tropical products was linked to the European economy on which the country, dependence (FURTADO, 2005).

At that time, Maranhao lived moments of prosperity, but the political conflicts between Portugal and England harmed the province, hampering the advance of the competitiveness in which it affected the economic development of Brazil even, generated a climate of dissatisfaction in practically all the regions among them, the Maranhão (FURTADO, 2005).

It should be noted that Brazil-Colônia and Maranhão-Provincia, of old, did not have an independent policy that would support competitiveness with other countries, mainly with Europeans and because of the distance separating Portugal from Brazil, many forms were created of tax evasion was always present throughout colonial Brazil and that corruption was constant, which resulted in the worsening of the financial crisis in the country, since the tax system was not enough to raise funds for the country's central government (TRISTÃO, 2003 and FURTADO, 2005).

It can be seen that these problems caused Maranhão to go through the economic difficulties, since the sugar and cotton that were the local product presented a drop in prices and the per capita income was decreasing (FURTADO, 2005), since fiscal equipment which almost did not exist at the time, made financially the government's management worse because it aggravated the development of its functions.

However, the growth of the economy in Maranhão began in the 1980s, when an elite of the state itself decided to install the industry to take advantage of the local productive arrangement that was cotton so, also brought the urban transformations because, where the factories were installed, were (FURTADO, 2005), but after the boom in the cotton economy went to a situation of poverty (BARBOSA, 2012).

It is recalled that the factories established in the 1980s in Maranhão failed to create a dynamic industrial system to the point of resisting competitors in the south of the country or achieving the competitiveness that cotton reached 
in the international markets, which resulted in the closure of the doors of all industries in Maranhão (FURTADO, 2005).

It is perceived that, in that decade, there was a revolution because, the Federal Constitution of 1988 was born, then the Public Policies, previously generated through centralized state planning, began to change from a State Reform, in particular, Administrative Reform in the sector public, based on political-administrative decentralization and deconcentration, resulting in an Administrative Regionalization (FIGUEIREDO, 2009)

It is understood that the Maranhão do XXI is different from the province of the nineteenth century because, the state at the moment, enjoys a modern reality in that it offers a better structure for companies to settle, but, it is understood that the dynamics to advance the process of product competitiveness may require more investments in infrastructure, skilled labor, even in logistics, therefore, in a balanced way, these factors must be above any proposed tax benefit because, according to Santana $(2016$, p.1) "Excessive public spending or too much use of fiscal incentives can lead a country to its instability and this was the model adopted by Brazil between the years 2002-2015."

It is believed that tax incentives have two distinct points that involve public policies because, on the one hand, there are investors who want incentives; on the other hand, there is a state with its structural limitations in which it can demonstrate the fragility in the concrete implementation of the public policies (ARAGÃO, 2005).

Therefore, despite the modern era, regional development in Maranhão has not progressed since it continues to be one of the poorest federative unit in the northeastern region and in the country, therefore, it has great needs and few social indicators that influence income and economic structure and This has aggravated the poor supply of public services (CARVALHO, 2015) while this process remains in these conditions, the state also remains poor and with poor social indicators.

\section{Research Methodology}

Due to the number of fiscal incentives that have arisen in the State of the State, this study resolves to be limited to the period from 2008 to 2017. For this, this methodology was divided in two steps: bibliography and field research.

In order to analyze fiscal incentives and their capacity to generate employment and income in Maranhão, it was necessary to call upon the State Treasury Department (SEFAZ-MA) through access to information on which the list of active tax incentives in Maranhão was requested, the exclusive tax incentives to generate jobs and income and the main economic activities that benefited from such incentives.

A search was then made on the website of the Ministry of Labor and Social Security (MTE) on the jobs generated in each economic activity encouraged, but for that, it was necessary to use the login and password provided by the public agency and, thus, , check the evolution of jobs between the established periods.

By collecting the data in SEFAZ-MA and MTE, the information was coded and analyzed through statistics and then transformed into graphs, but analyzed based on the Person's coefficient.

Pearson's and Stanton's (2001, p. 1) correlation coefficient is a measure of bivariate association (strength) of the degree of relationship between two variables. For Moore (2007), correlation measures the direction and degree of the linear relationship between two quantitative variables (Moore, 2007, pp. 100 and 101).

According to Figueiredo Filho and Silva Júnior (2009, p. 118) the Pearson correlation coefficient (r) is a measure of linear association between variables. For Figueiredo Filho and Silva Júnior (2009, p. 118), the Pearson correlation case ( $r$ ) is worth the latter parameter, that is, it is a measure of the shared variance between two variables. On the other hand, the linear model assumes that the increase or decrease of a unit in the variable $\mathrm{X}$ generates the same impact in Y. In graphical terms, by linear relation it is understood that the best way to illustrate the pattern of relationship between two variables is through a straight line. Therefore, the Pearson correlation (r) requires a sharing of variance and that this variation is linearly distributed (FIGUEIREDO FILHO AND SILVA JÚNIOR, 2009).

According to Figueiredo Filho and Silva Júnior (2009, p. 119), the Pearson correlation coefficient (r) varies from -1 to 1 . In the Person correlation coefficient, the values can indicate positive or negative direction of the relationship and even show strength of the relationship between variables, so a correlation to make perfect (-1 or 1$)$ must necessarily be exact, but also, if the value of a correlation is zero indicates that there is no linear relationship between the variables. 
However, extreme values ( 0 or 1$)$ are difficult to find in practice, it is important to discuss how researchers can interpret the magnitude of the coefficients (FIGUEIREDO FILHO \& SILVA JÚNIOR, 2009).

Therefore, Cohen (1988) says that values between 0.10 and 0.29 can be considered small; scores between 0.30 and 0.49 can be considered as mean; and values between 0.50 and 1 can be interpreted as large and for Dancey and Reidy (2005) they point to a slightly different classification: $r=0.10$ up to 0,30 (weak); $r=0.40$ to 0.6 (moderate); $\mathrm{r}=0.70$ to 1 (strong).

Therefore, it is known that the closer to 1 the greater the degree of linear statistical dependence between the case variables, otherwise, the closer to zero, the lower the strength of this relation.

Therefore, the methodology used in this study respected the phases of field research and the quantitative-descriptive method.

\section{Summary of Tax Benefits to Promote Economic Development, Employment and Income in Maranhão}

According to information provided by the Finance Ministry of Maranhão (SEFAZ-MA), the state currently has 19 active tax incentives. See table 01.

Table 1. The tax incentives offered by the government of Maranhão in accordance with the legislation and the form of the benefit

\begin{tabular}{ll}
\hline Legislation & Creation Date \\
\hline Decree $\mathrm{n}^{\circ} 31.287$ & $09 / 11 / 2015$ \\
Decree $\mathrm{n}^{\circ} 30.680$ & $18 / 03 / 2015$ \\
Law $\mathrm{n}^{\circ} 10.259$ & $16 / 06 / 2015$ \\
Law $\mathrm{n}^{\circ} 10.267$ & $24 / 06 / 2015$ \\
Law $\mathrm{n}^{\circ} 10.349$ & $20 / 10 / 2015$ \\
Law $\mathrm{n}^{\circ} 10.386$ & $21 / 12 / 2015$ \\
Law $\mathrm{n}^{\circ} 10.301$ & $27 / 08 / 2015$ \\
Decree $\mathrm{n}^{\circ} 31.133$ & $18 / 09 / 2015$ \\
Decree $\mathrm{n}^{\circ} 32.196$ & $21 / 09 / 2016$ \\
Decree $\mathrm{n}^{\circ} 31.535$ & 2016 \\
Decree $\mathrm{n}^{\circ} 31.624$ & $15 / 04 / 2016$ \\
Decree $\mathrm{n}^{\circ} 31.534$ & $11 / 03 / 2016$ \\
Law $\mathrm{n}^{\circ} 10.504$ & $06 / 09 / 2016$ \\
Law $\mathrm{n}^{\circ} 10.506$ & $06 / 09 / 2016$ \\
Provisional measure $\mathrm{n}^{\circ} 252$ & $01 / 09 / 2017$ \\
Provisional measure $\mathrm{n}^{\circ} 251$ & $25 / 08 / 2017$ \\
Provisional measure $\mathrm{n}^{\circ} 246$ & $7 / 08 / 2017$ \\
Provisional measure $\mathrm{n}^{\circ} 245$ & $7 / 08 / 2017$ \\
Decree $\mathrm{n}^{\circ} 33.110$ & $14 / 07 / 2017$ \\
\hline 8. (Dados 0rgazad & pelos \\
\hline
\end{tabular}

Source: SEFAZ - MA, 2018. (Dados organizados pelos autores).

In summary, the fiscal incentives offered by the government of Maranhão currently have the following purposes: a fiscal incentive is designed to stimulate the consumption of regional products; two incentives are aimed at stimulating the regularization of ICMS debts; three are aimed at stimulating the implantation and expansion of companies; four are aimed at stimulating the generation of jobs and income; five of them aim to stimulate production in the state and the other four tax incentives were created for other purposes.

\section{Analysis of the Economic Situation of Maranhão in Relation to Current Fiscal Incentives}

5.1 Analyzing the Relation of the Balance of Jobs Between Incentivized Economic Activities and All the Economic Sectors of Maranhão

Figure 1 shows an association between two variables being: absolute employment variation in the entire state ex: absolute change of jobs in the economic sectors stimulated in Maranhão between 2008 and 2017. Note that the absolute variation of jobs refers to the total value of hirings minus the dismissals of employees in each period. See chart 01 . 


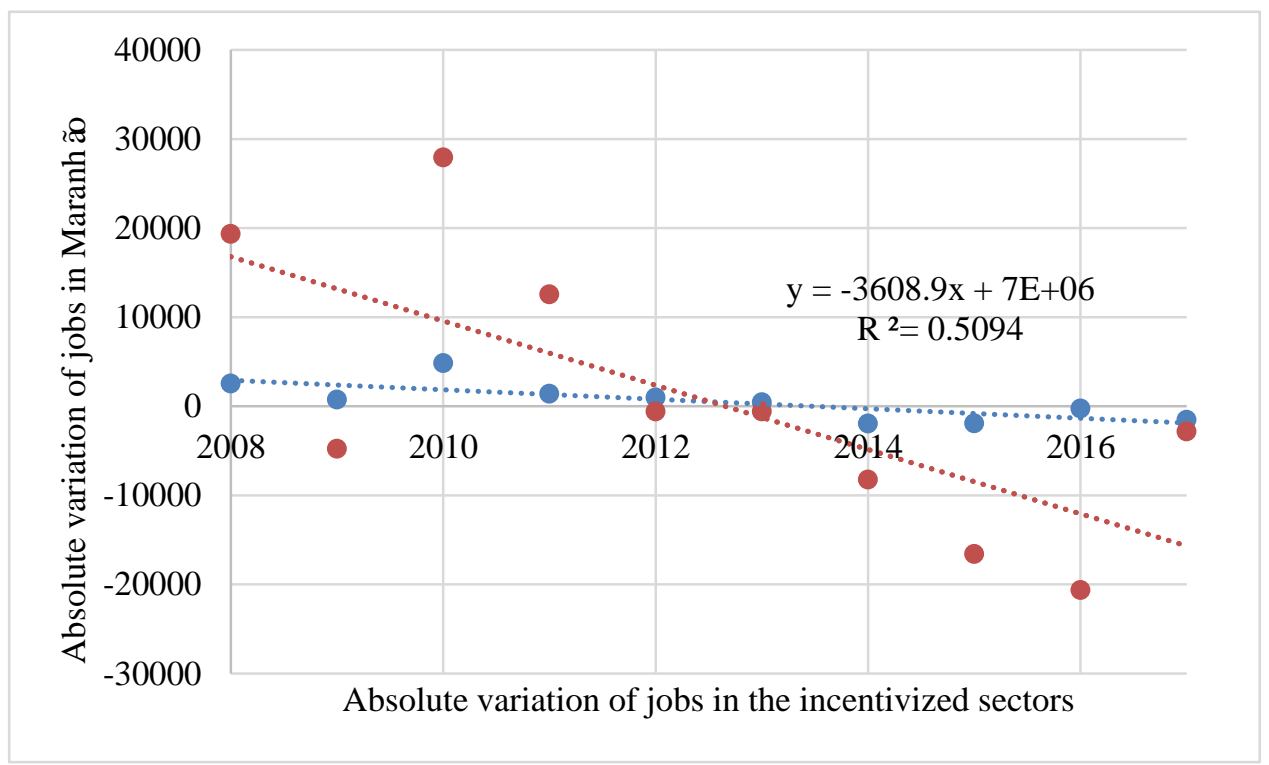

Figure 1. Absolute variation of jobs in Maranhão

Source: MTE (2018). (Data organized by the authors).

Analyzing by means of the variables, the relation between jobs in the sectors stimulated by all sectors of the economy in Maranhão, it is perceived that there is a positive linear correlation, since $\mathrm{R}^{2}=0.5094$, however, it is considered a moderate relation ( DANCEY \& REIDY, 2005).

It is revealed, based on the linear coefficient, that the fiscal incentives and jobs in Maranhão had, in some periods, the following impacts:

- In 2010, Maranhão in general received the largest balance of jobs with a value of 27,937 , and economic sectors such as industry, wholesale trade, dairy products, horticulture and agriculture, known as family agriculture benefiting from the incentives, had a balance of 4,849 this highlights the strength of the incentivized sector and its relevance in the generation of employment and income in the state;

- However, in 2015 and 2016, economic sectors benefiting from tax incentives had a balance of (-1926) and (-272), being $11 \%$ and $1.31 \%$ in relation to the other economic sectors $(-16,586)$ and $(-20,634)$, so it is important to note that, in any case, fiscal incentives in Maranhão were fundamental because, despite the negative balances, it can be noted that the state is recovering economically, thus reducing the impact on the economy by almost 10\%. employment balance in 2016 compared to 2015 .

5.2 Analyzing the Correlation of the Jobs Generated by the Incentive Activities in Maranhão and With the Jobs Generated by the Same Economic Activity in Northeast Brazil

In Figure 2 an analysis was made considering the variable y: the balance of jobs in Maranhão and the variable x: the balance of jobs in the northeast between 2008 and 2017. 


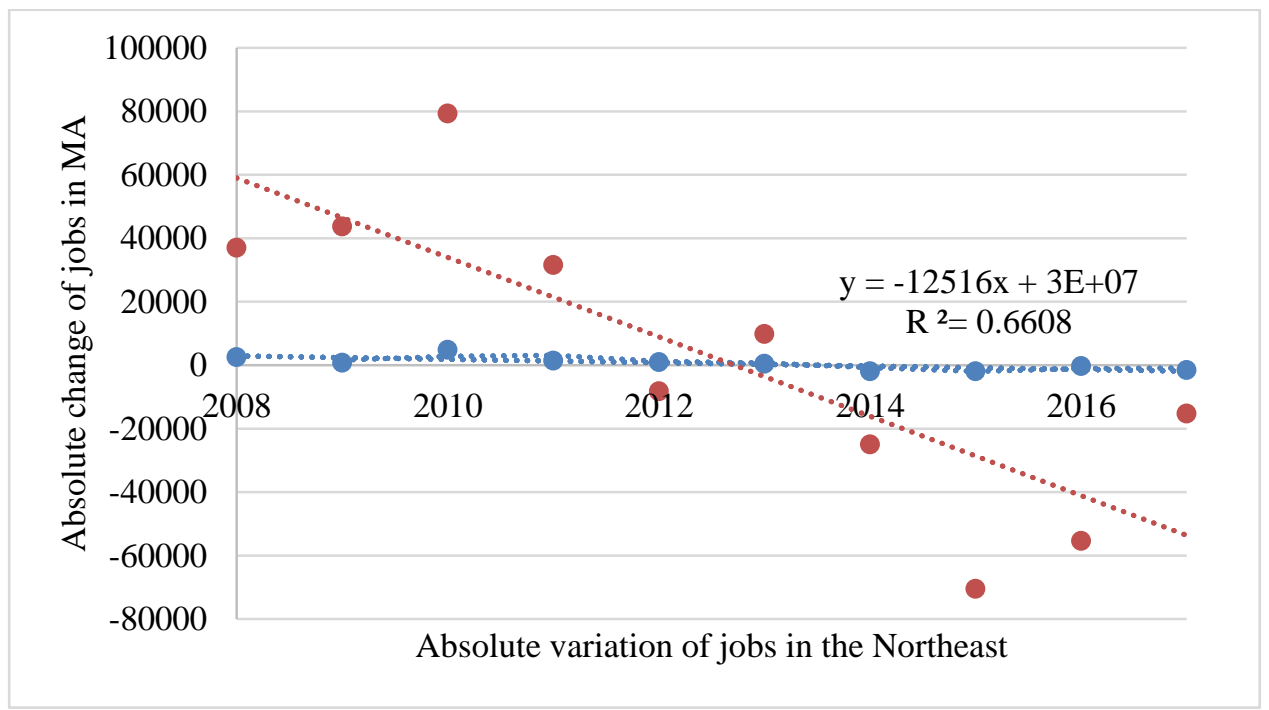

Figure 2. Absolute variation of jobs in Maranhão and Northeast Brazil

Source: MTE (2018). (Data organized by the authors).

At the beginning, the study shows that, between the analyzed periods, there was a moderate positive linear correlation, since Dancey and Reidy (2005) point to a moderate classification when (r) varies between 0.40 and 0.6 in the table of dispersion and in this case $\mathrm{R}^{2}=0.6608$.

It is understood that some points in figure 2 should be clarified as follows:

- In 2010, the economic reality of the Northeast was somewhat different from the economic situation in Maranhão, since the absolute employment variation index remained far from the linear trend line in relation to Maranhão in the same period;

- In 2012, Maranhão remains with the positive balance of jobs, while the balance of employment in the Northeast was negative;

- In 2013, Maranhão had a relationship close to the reality of the Northeast, revealing that the state of Maranhão has a fundamental role for the development of the Northeast;

- In 2015 and 2016, the negative employment balance affected all the states in the Northeast, but Maranhão had less impact in this relation, considering that in these two consecutive years, there was a relative distance between two variables, since these values are far from the point of linear dispersion.

Therefore, it is believed that the strong impact on the negative balance of jobs in Maranhão and in the Northeast probably comes from the economic crisis that Brazil is suffering.

Thus, it suggests that Maranhão seeks to improve public policies to generate employment and income, because, although it has created fiscal incentives to stimulate production, competition, consumption, job creation and income, these measures were not sufficient for the economic development in relation to other states of the federation.

5.3. Verifying the Relation of the Balance of Jobs in the Incentivized Activities With the Performance of the State GDP in Maranhão

It is understood that regional development is linked to the growth of gross domestic product (GDP). Figure 3 shows the absolute variation of employment in the sector stimulated with the state GDP.

The analysis of the GDP will be based on the perspective of income in which it intends to verify if the performance of the employment has any relation with the economic growth of the state. 


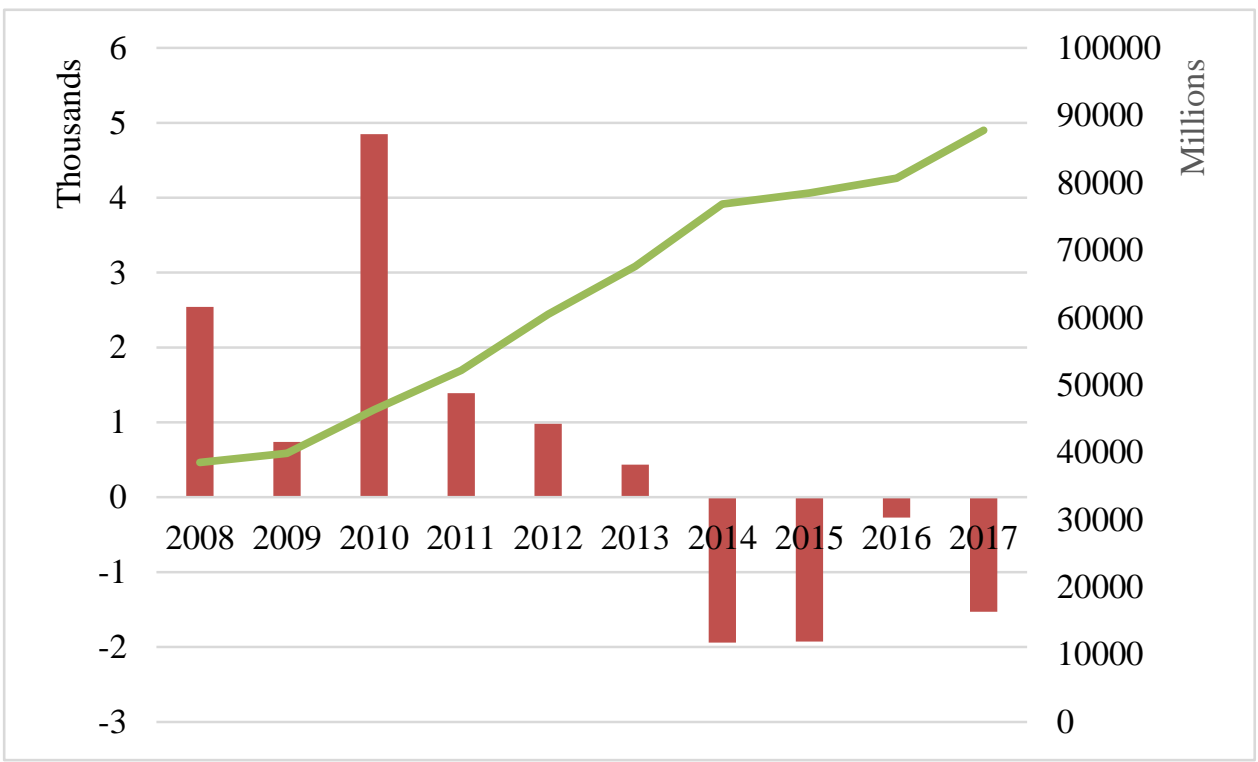

Figure 3. Economic situation of Maranhão in relation to jobs and state GDP

Source: IBGE (2014, 2017); IMESC (2018); MTE (2018). (Data organized by the authors).

Figure 3 shows that, in 2008 and 2010, jobs evolved in the same state in which the state GDP developed in the economic scenario of Maranhão. Although the balance of jobs generated between 2011, 2012 and 2013 is positive, it is worth mentioning that the balance of jobs decreased successively, while GDP maintained economic growth in the state. However, in 2014, 2015, 2016 and 2017, the balance of jobs was negative, that is, outside the economic reality of GDP, as it continued to grow.

\section{Final Considerations}

Looking to bring an answer to the problem of the question of this study it was evident that such fiscal incentives granted by the State of Maranhão between 2008 and 2017 failed to maintain the growth of the balance of jobs in the state in the last years $(2015,2016,2017)$, but in return, the encouraged economic sectors had fewer negative impacts than the other economic sectors in the region and this leads one to believe that, in any case, it stimulated regional development.

Therefore, the initial hypothesis that tax incentives in Maranhão stimulated firms to generate jobs, but unfortunately the incentive sectors were unable to maintain the same employment growth in relation to GDP, it is confirmed

Thus, it is suggested to future researchers, who seek to investigate other intrinsic factors on tax incentives that were not addressed in this research.

\section{References}

Amaral Filho, J.do. (2003). Tax incentives and state policies for attracting investments. Texts for Discussion, Institute of Research and Economic Strategy of Ceará (IPECE). Retrieved February 19, 2018, from https://www.ipece.ce.gov.br/textos_discussao/TD_8.pdf

Aragão, F.J.P. (2005). The social impact of the fiscal incentives policy in the state of Ceará: the case of Maranguape. Dissertation (MSc in Public Policies and Society). State University of Ceará (Uece)-Center for Humanities and Center for Applied Social Studies, Fortaleza. Retrieved February 23, 2018, from http://www.uece.br/politicasuece/dmdocuments/francisco_jairo_paixao_aragao\%5B1\%5D.pdf

Barbosa, F.B.da.C. (2018). Economy of Maranhão and São Paulo: similarity in origin, discontinuity in development. Retrieved February $22, \quad 2018, \quad$ from http://www.ipades.com.br/publicacoes/ECONOMIA-DO-MARANHAO-E-DE-SAO-PAULO-SEMELHANCA -NA-ORIGEM-DESCONTINUIDADE-NO-DESENVOLVIMENTO.pdf.

Bercovici, G. (2003). Regional inequalities, state and constitution. São Paulo: Max Limonad. 
Brazil. Law no. 12,527, dated November 18, 2011. Regulates access to information provided in item XXXIII of art. 5, item II of paragraph 3 of art. 37 and in $\S 2$ of art. 216 of the Federal Constitution; amends Law No. 8,112 of December 11, 1990; revokes Law No. 11,111, of May 5, 2005, and provisions of Law No. 8.159, of January 8, 1991; and makes other arrangements.

Carvalho, F.C.de. (2015). Regional-territorial development policy and governance: A recent analysis on the State of Maranhão (Brazil). Thesis (doctorate)-Institute of Geosciences and Exact Sciences, Universidade Estadual $\begin{array}{lllll}\text { Paulista. } & \text { Jetrieved 23, } & \text { 2018, }\end{array}$ repositorio.unesp.br/bitstream/handle/11449/138539/000864210.pdf?sequence=1

Cohen, J. (1998). Statistical power analysis for the behavioral sciences. Hillsdale, NJ, Erlbaum.

Constantino, M., Pegorare, A.B., \& Costa, R.B. da. (2016, April/June). Regional performance of the HDI and GDP per capita of the municipalities of Mato Grosso do Sul, Brazil, between 2000 and 2010. Revista: INTERAÇÕES, Campo Grande, MS, 17(2), 234-246. Retrieved February 20, 2018, from http://www.scielo.br/pdf/inter/v17n2/1518-7012-inter-17-02-0234.pdf

Dancey, C., \& Reidy, J. (2006). Statistics Without Mathematics for Psychology: Using SPSS for Windows. Porto Alegre, Artmed.

Figueiredo Filho, D.B., \& Silva Júnior, J.DA. (2009). Unraveling Ministries of Pearson's Correlation Coefficient (r). Revista Política Hoje, 18(1). Retrieved January 30, 2018, from https://www.google.com/url?sa=t\&rct=j\&q=\&esrc=s\&source=web\&cd=1\&ved=0ahUKEwjDz87U55_JAhXMr pAKHRVaBY8QFgggMAA\&url=http\%3A\%2F\%2Fwww.revista.ufpe.br\%2Fpoliticahoje\%2Findex.php\%2Fpo litica\%2Farticle\%2FviewFile\%2F6\%2F6\&usg=AFQjCNG1QfVVdplHcuhmm8rYnQMWpVxlvA

Figueiredo, A.M. (2009). Policies and regional development planning. In COSTA, José da Silva, NIJKAMP, Peter (Org.), Compendium of Regional Economics: Theory, Themes and Policies (Vol. 1). Coimbra: Principia.

Furtado, C. (2005). Economic formation of Brazil (3rd ed.). Companhia Editora Nacional. São Paulo.

Gerhardt, T.E. (2009). The construction of the research. In GERHARDT, T.E. \& SILVEIRA, D.T. (Org.), Research Methods. Porto Alegre: Publisher of UFRGS.

Imesc. (2016, July/October). Maranhense Institute for Economic and Cartographic Studies. Bulletin of economic conjuncture, 4(2). São Luís-Maranhão.

Lakatos, E.M., \& Marconi, M. de A. (2003). Fundamentals of scientific methodology (5th ed.). São Paulo: Atlas.

Lime. F.S. (2015). Relationship between centroproduc and the single distribution center: a study on the fiscal incentive in the city of goiânia. Dissertation (Master in Regional Development)-Faculdades Alves Faria, Goiânia.

Moore, D.S. (2007). The Basic Practice of Statistics. New York, Freeman.

Santana, J.M.B et al. (2016). The theory of public choice and the social cost of the decision between public spending and the renunciation of revenue. Spaces, 37(35), 25. Retrieved February 18, 2018, from http://www.revistaespacios.com/a16v37n35/16373526.html

Stanton, J.M.G. (2001). Pearson, and the peas: A brief history of linear regression for statistics instructors. Journal of Statistical Education, 9, 31. Retrieved January 5, 2018, from http://www.amstat.org/publications/JSE/v9n3/stanton.html

Tristão, J.A.M. (2003). The tax administration of the Brazilian municipalities: An evaluation of the performance of the collection. Thesis ( $\mathrm{PhD}$ doctorate in administration), EAESP / FGV, São Paulo.

Vergara, S.C. (2016). Research projects and reports in administration (16th ed.). São Paulo: Atlas. 